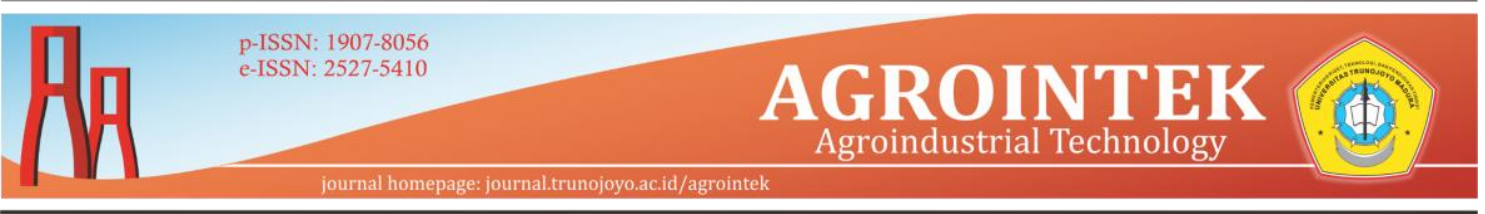

\title{
ANALISIS BEBAN KERJA KARYAWAN PADA BAGIAN SORTASI DI PT. PERKEBUNAN NUSANTARA $X$, KABUPATEN JEMBER
}

Mita Lutfifatima Puspitawati ${ }^{1}$, Ida Bagus Suryaningrat ${ }^{1}$, Andrew Setiawan Rusdianto ${ }^{1 \dagger}$

${ }^{1}$ Jurusan Teknologi Industri Pertanian,Universitas Jember, Jember

Article history

Diterima: 20 Februari 2019

Diperbaiki: 14 Mei 2019

Disetujui: 17 Juni 2019

$\underline{\text { Keyword }}$

workload, \% CVL

(Cardiovasculair), NASA-

$T L X$

\begin{abstract}
PT. Perkebunan Nusantara X Kertosari Field, Jember Regency is an agroindustry company that produces high quality tobacco leaves. PT Perkebunan Nusantara X workers in Kertosari Gardens have different position of work such as sorting, transporting and distributing materials with variation of work position (standing and sitting) that it can create workload. Workload problems can be effect on concentration, performance, product quality, and occupational health. These studies aims are to be determining the worker physiological and psychological workload with standing and sitting positions and providing recommendations to reduce workload in the sorting section. The method is the measurement of physical workload using the pulse manually which is done 3 times namely before work (DNI), work (DNK), and at rest (recovery) then calculated with \% CVL. The results obtained by \% CVL workers aged 20 - 40 years with standing work positions are more dominant experiencing physical workload with a value of $>30 \%$. In addition, the method used to measure mental workload is NASA-TLX with two stages, namely the weighting stage and the rating stage. The result obtained by the WWL value of workers aged 20 years and 40 years is $>80$ so that it has a medium to severe mental workload.

(C) hak cipta dilindungi undang-undang
\end{abstract}

\footnotetext{
$\dagger$ Penulis korespondensi

Email: andrew.ftp@unej.ac.id

DOI: http://dx.doi.org/10.21107/agrointek.v13i2.5007
} 


\section{PENDAHULUAN}

Jember merupakan salah satu Kabupaten yang menjadi kota penghasil tembakau dengan kualitas baik. PT Perkebunan Nusantara X Kebun Kertosari merupakan salah satu perusahaan yang bergerak dalam pengolahan tembakau. Produksi tembakau memiliki persyaratan kualitas yang baik dalam pengolahannya. Produksi tembakau dari tahun ke tahun mengalami peningkatan, di tahun 2016 PTPN X Kertosari mampu memproduksi tembakau sebanyak $234.444 \mathrm{~kg}$ dan meningkat di tahun 2017 sebanyak 274 . $880 \mathrm{~kg}$.

Kegiatan proses produksi tembakau merupakan aktivitas yang membutuhkan tenaga kerja yang cukup banyak terutama di bagian sortasi. Proses sortasi dilakukan pemisahan produk berdasarkan fisik seperti bentuk, ukuran, warna dan lainnya. Proses sortasi dilakukan secara manual dengan menggunakan tenaga manusia. Menurut kepala bagian produksi, proses sortasi sangat menentukan kualitas tembakau. Umumnya pekerjaan tersebut dilakukan oleh pekerja wanita dengan usia yaitu sekitar 20 tahun - 50 tahun dengan jam kerja yang dimulai pukul 07.00 sampai pukul 16.00 dengan kondisi kerja yang tidak menentu yaitu dengan posisi duduk dan posisi berdiri. Posisi tersebut dilakukan sesuai dengan keinginan pekerja dalam menyelesaikan pekerjaannya yang cukup banyak.

Beban fisik yang terlalu berat akan dapat menimbulkan kelelahan sehingga dapat berpengaruh pada jumlah produk (kuantitas) yang dihasilkan per harinya. Beban kerja yang berlebih dapat menimbulkan suasana yang kurang nyaman dan juga dapat menimbulkan stres kerja. Kenyamanan pekerja merupakan aspek yang penting dalam suatu perusahaan. Pekerja akan dapat bekerja dengan baik dan mencapai hasil yang optimal apabila kondisi pekerja mendukung. Setiap perusahaan membutuhkan tenaga kerja dalam melakukan produksi, sehingga tenaga kerja menjadi faktor yang dapat mempengaruhi produktivitas perusahaan.

Oleh karena itu perlu dilakukan pengukuran beban kerja pekerja bagian sortasi untuk mengetahui sampai sejauh mana beban kerja baik fisik maupun mental yang dialami oleh pekerja.

Beban kerja mental dapat diketahui dengan menggunakan metode NASA-TLX (National Aeronautics and Space Administration-Task Load Indeks), sedangkan beban kerja fisik dapat diketahui dengan menggunakan metode \% CVL (Cardiovasculair Load) dan metode Brouha dengan pengukuran denyut nadi pekerja sebelum melakukan kegiatan, saat bekerja dan saat istirahat (pemulihan).

\section{METODE}

Penelitian ini dilaksanakan di di PT. Perkebunan Nusantara X Kebun Kertosari, Kabupaten Jember dengan objek penelitian di bagian sortasi pada bulan Juni hingga Agustus 2018. Penelitian ini menggunakan responden sebanyak 54 orang yang terdiri dari pekerja sortasi usia 20 tahun - 40 tahun dan pekerja sortasi > 40 tahun dengan menggunakan perbandingan posisi berdiri dan posisi duduk. Jumlah responden didapatkan dengan menggunakan perhitungan slovin dengan tingkat kepercayaan 90\%. Pengambilan sampel dilakukan dengan menggunakan metode random sampling dengan kriteria penentuan responden yaitu dipilih secara acak tanpa melihat strata.

Penelitian pendahuluan dilakukan melalui wawancara serta survei langsung ke lokasi (observasi) untuk mencari informasi mengenai permasalahan yang sering dirasakan pekerja seperti adanya keluhan pada pekerja akibat beban kerja yang dirasakan. Setelah diperoleh 
informasi mengenai permasalahan tersebut, kemudian dilakukan pengumpulan data primer dan data sekunder. Data primer didapatkan dengan melakukan pengukuran beban kerja berupa fisiologis dan psikologis. Pengukuran beban kerja fisiologis dilakukan secara langsung pada bagian tangan pekera dengan 3 fase waktu yaitu sebelum bekerja (DNI), saat bekerja (DNK), dan saat istirahat (nadi pemulihan). Selanjutnya hasil pengukuran denyut nadi tersebut dilakukan analisis dengan \% CVL (Cardiovasculair Load) dan metode Brouha yang bertujuan.untuk mengetahui bagaimana denyut nadi pekerja saat melakukan istirahat. Menurut (Mutia, 2014), Cardiovascular Load (\% CVL) dapat dihitung dengan menggunakan rumus sebagai berikut :

$$
\% C V L=100 \times \frac{D N K-D N I}{D N M a k s-D N I}
$$

Dimana untuk menentukan \% CVL diketahui bahwa denyut nadi maksimum adalah 200/menit untuk wanita. Dari hasil perhitungan $\%$ CVL kemudian dibandingkan dengan ketetapan seperti pada Tabel 1.

Sedangkan pengukuran beban kerja psikologis dilakukan dengan menyebar kuisoner NASA-TLX dengan 6 indikator yaitu Kebutuhan Mental (KM), Kebutuhan Waktu (KW), Kebutuhan Fisik (KF), Performansi (P), Tingkat Frustasi (TF) dan Tingkat Usaha (Okitasari dkk, 2016). Metode NASA-TLX dilakukan dua tahapan yaitu tahapan pembobotan dan tahapan rating.

\section{Tahap pembobotan}

Pada tahap ini, pekerja memilih satu indikator yang paling berpengaruh bagi pekerja. Kemudian pilihan-pilihan indikator tersebut kemudian diolah untuk menghitung bobot dari masing-masing indikator dan bobot ini akan digunakan pada tahapan kedua.
2. Tahap rating

Pada tahapan ini, pekerja akan memberikan peringkat atau rating pada setiap indikator sesuai dengan beban kerja yang dirasakan subyek berkaitan dengan indikator tersebut dengan rentang skala peringkat 0-100.

Tabel 1 Ketetapan Cardiovasculair

\begin{tabular}{cl}
\hline \multicolumn{1}{c}{ Nilai } & \multicolumn{1}{c}{ Indikator } \\
\hline$<30 \%$ & $\begin{array}{l}\text { Tidak terjadi } \\
\text { kelelahan }\end{array}$ \\
$30 \%-60 \%$ & $\begin{array}{l}\text { Diperlukan perbaikan } \\
60 \%-<60 \%\end{array}$ \\
$\begin{array}{l}\text { Kerja dalam waktu } \\
\text { singkat }\end{array}$ \\
$80 \%-<100 \%$ & $\begin{array}{l}\text { Diperlukan tindakan } \\
\text { segera } \\
\text { Tidak diperbolehkan } \\
\text { beraktivitas }\end{array}$ \\
\hline
\end{tabular}

\section{HASIL DAN PEMBAHASAN \\ Analisis Timbulnya Beban Kerja Fisik dan Mental}

Jumlah tugas atau pekerjaan yang banyak dan harus diselesaikan oleh pekerja bagian dalam jangka waktu sekitar 8 jam dalam sehari seharusnya didukung oleh keadaan tempat kerja yang ergonomis sehingga pekerja merasa nyaman dengan pekerjaannya. Menurut Sedamaryanti (2011), pekerjaan atau aktivitas yang dilakukan apabila tidak ergonomis maka akan mengakibatkan ketidaknyamanan kerja, menimbulkan penyakit akibat kerja yang meningkat, perfomansi yang menurun dan daya kerja yang menurun juga.

Jenis pekerjaan yang dilakukan oleh pekerja sortasi antara usia 20 tahun -40 tahun dan pekerja sortasi usia $>40$ tahun memiliki perbedaan dan dilakukan dengan posisi berdiri dan posisi duduk. Adapun pekerjaan yang akan diukur pada bagian sortasi dengan beberapa kriteria yang diperlukan seperti posisi kerja bagian 
sortasi, jam atau waktu kerja yang dimulai pada jam 07.30 hingga 16.00 yaitu selama \pm 8 jam, dan jenis pekerjaan yang dilakukan. Pekerja di setiap divisi mempunyai tugas pokok yang sama, namun mempunyai perbedaan pada unsur tugas pada setiap pekerjaannya. Perbedaan aktivitas pekerja sortasi dengan beda usia dapat dilihat pada Gambar 1.

Hermawan et al (2013) berpendapat bahwa pengalaman lama bekerja tidak serta merta dapat mengurangi tingkat beban kerja seseorang. Pekerja di usia $>40$ tahun memiliki pekerjaan yang lebih

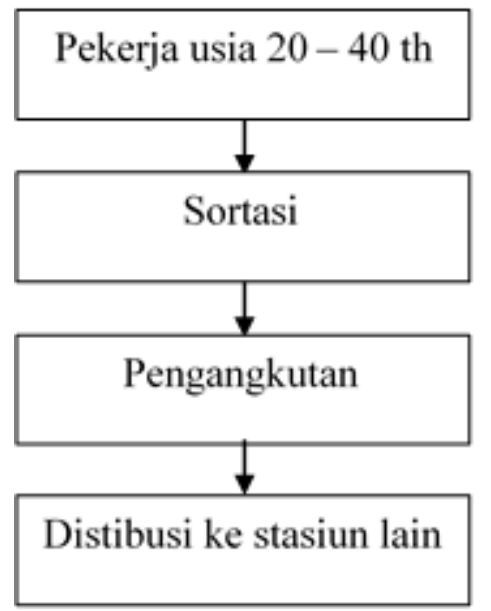

Gambar 1 deskripsi Pekerjaan Bagian Sortasi

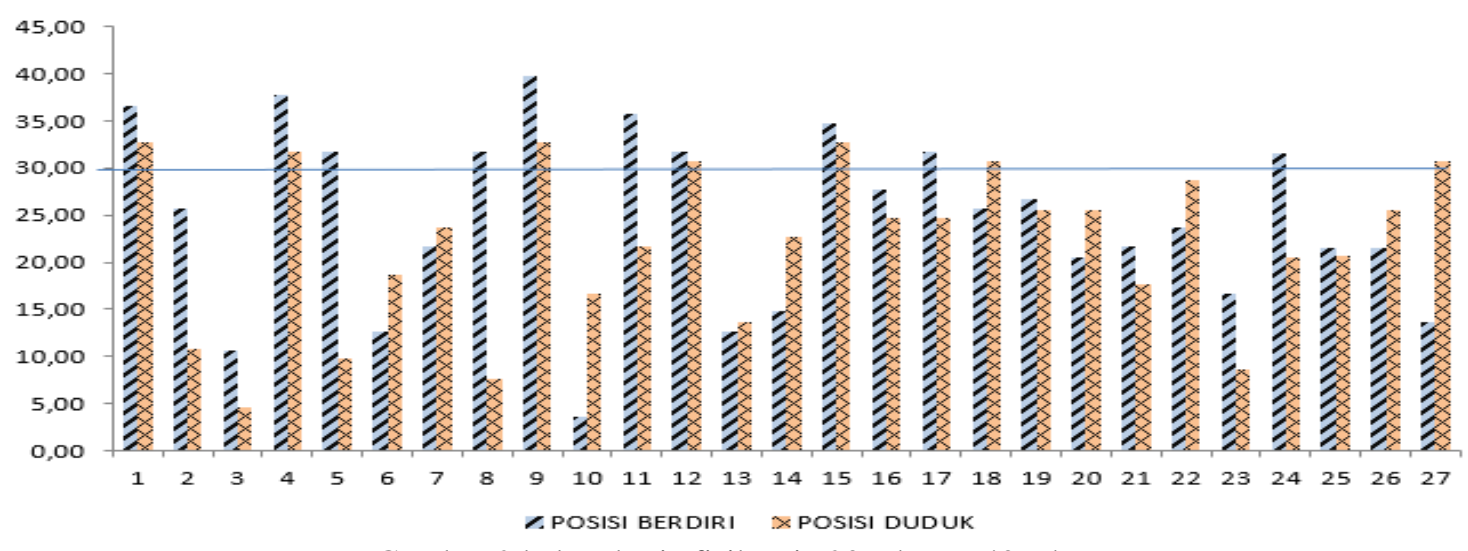

Gambar 2 beban kerja fisik usia 20 tahun - 40 tahun

Beban Kerja Fisiologis dengan Metode \% CVL (Cardiovasculair)

Penentuan beban kerja fisiologis dengan mengukur jumlah denyut nadi pekerja usia 20 tahun - 40 tahun dan $>40$ ringan daripada pekerja usia 20 tahun -40 tahun. Tanggung jawab dan target kerja yang diberikan perusahaan kepada setiap pekerja adalah sama, hanya saja mayoritas pekerja di usia > 40 tahun melakukan pekerjaan sortasi dengan santai dan tidak terlalu banyak mengeluarkan tenaga (semampunya). Menurut Sedarmayanti (2011), umur seseorang berbanding langsung dengan kapasitas fisik sampai batas tertentu, yaitu pada usia 25 tahun dan usia 50 tahun - 60 tahun kekuatan otot menurun sebesar 25, kemampuan sensoris dan motoris juga mengalami penurunan sebanyak $60 \%$.

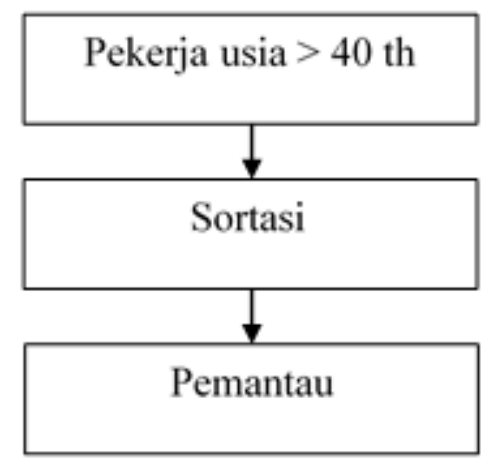

tahun dengan perbandingan posisi kerja yaitu posisi berdiri dan posisi duduk. Data pengukuran denyut nadi sebelum dan sesudah bekerja digunakan sebagai data perhitungan \% CVL.. Pengukuran beban 
kerja fisiologis pekerja pada bagian sortasi daun tembakau adalah sebagai berikut:

1. Pekerja sortasi usia 20 tahun -40 tahun

Berdasarkan hasil pengukuran denyut nadi sehingga didapatkan grafik hasil persentase beban kerja fisik dengan metode $\%$ CVL (\% Cardiovasculair ) di usia pekerja 20 tahun - 40 tahun seperti pada Gambar 2.

Berdasarkan Gambar 2 dapat dilihat bahwa posisi berdiri memiliki persentase beban kerja yang lebih tinggi daripada kegiatan dengan posisi duduk dimana pada Tabel 1 dijelaskan apabila nilai berada diantara $30 \%-60 \%$ termasuk indikator beban kerja yang perlu dilakukan perbaikan sedangkan nilai yang berada < $30 \%$ termasuk indikator beban kerja fisik yang tidak terjadi kelelahan. Menurut Hermawan et al (2013) berpendapat bahwa beban kerja fisik yang cukup berat menunjukkan aktivitas kerja yang dimiliki pekerja beragam dan memiliki tanggung jawab besar terhadap perusahaan. Terdapat 10 pekerja dari keseluruhan pekerja yaitu 27 pekerja dengan posisi berdiri dimana 37 $\%$ pekerjanya termasuk kriteria mengalami beban kerja fisik cukup berat. Sedangkan pada posisi duduk terdapat 7 dari 27 pekerja terdapat $26 \%$ pekerjanya termasuk kriteria mengalami beban kerja fisik cukup berat. Hal tersebut disebabkan karena beberapa faktor seperti usia dan tugas pekerja yang berbeda pada waktu yang sama.

Bekerja dengan posisi kerja berdiri Pada sikap kerja berdiri ternyata mempunyai rerata nadi kerja dan \% CVL yang paling tinggi dibandingkan dengan sikap kerja duduk. Hal tersebut disebabkan karena berdiri merupakan sikap yang tidak stabil di dalam mempertahankan keseimbangan seluruh tubuh. Aktivitas yang dilakukan dengan posisi berdiri dapat mempengaruhi cepatnya kelelahan pada saat bekerja, karena posisi ini membutuhkan semua anggota tubuh untuk bekerja. Kelelahan tersebut muncul di bagian-bagian tertentu seperti punggung, lutut, dan bagian leher karena melakukan pekerjaannya dengan posisi berdiri sedangkan desain meja yang terlalu rendah sehingga tidak seimbang. Akibat adanya ketidaknyamanan pada saat bekerja, pekerja sortasi usia 20 tahun - 40 tahun hanya menghasilkan $25-30 \mathrm{~kg} / \mathrm{hari}$ dan tidak dapat memenuhi target produksi perusahaan. Menurut Tarwaka et al (2004), menjelaskan bahwa pada dasarnya berdiri itu sendiri lebih melelahkan daripada duduk dan energi yang dikeluarkan untuk berdiri lebih banyak $10-15 \%$ dibandingkan dengan duduk.

Pada pekerjaan yang dilakukan dengan posisi duduk memiliki beban keja fisik yang lebih rendah daripada bekerja dengan posisi berdiri. Pekerja beban kerja fisik ringan lebih sering melakukan aktivitas sortasi ditempat duduk dan mengoper produk ke pekerja yang berada di satu wilayah (bersebelahan), sehingga tenaga fisik yang digunakan tidak terlalu banyak. Para pekerja tersebut merasa lebih nyaman bekerja dengan posisi duduk karena proses sortasi memerlukan ketelitian selain itu, pekerja tidak merasa lelah karena semua otot dan organ tubuh tidak bekerja. Menurut Grandjean (1993) dalam Tarwaka et al (2004) bekerja dengan posisi duduk mempunyai keuntungan antara lain: pembebanan pada kaki berkurang, pemakaian energi yang sedikit, dan keperluan untuk sirkulasi darah dapat dikurangi.

Jenis pekerjaan yang berbeda akan mempengaruhi kerja otot pada tubuh. Beban pekerjaan fisik yang semakin berat akan mempengaruhi kerja tubuh antara lain perubahan denyut nadi. Denyut nadi dan kekuatan memiliki kepekaan yang cukup tinggi terhadap perubahan beban kerja yang diterima oleh tubuh. Menurut 
Maharja (2015), beban kerja fisik yang semakin tinggi dapat menurunkan kekuatan dan kecepatan kontaksi otot yang menunjukkan kerja otot semakin melemah.

2. Pekerja sortasi usia $>40$ tahun

Pekerja dengan usia di atas 40 tahun merupakan pekerja yang masih diperbolehkan bekerja di PTPN X. Pekerja sortasi dengan usia lebih dari 40 tahun masih mampu untuk bekerja sesuai dengan standar yang ada dan mempunyai produkstivitas kerja yang baik. Adapun grafik hasil persentase beban kerja fisik dengan metode \% CVL ( \% Cardiovasculair ) di usia pekerja $>40$ tahun seperti pada Gambar 3.

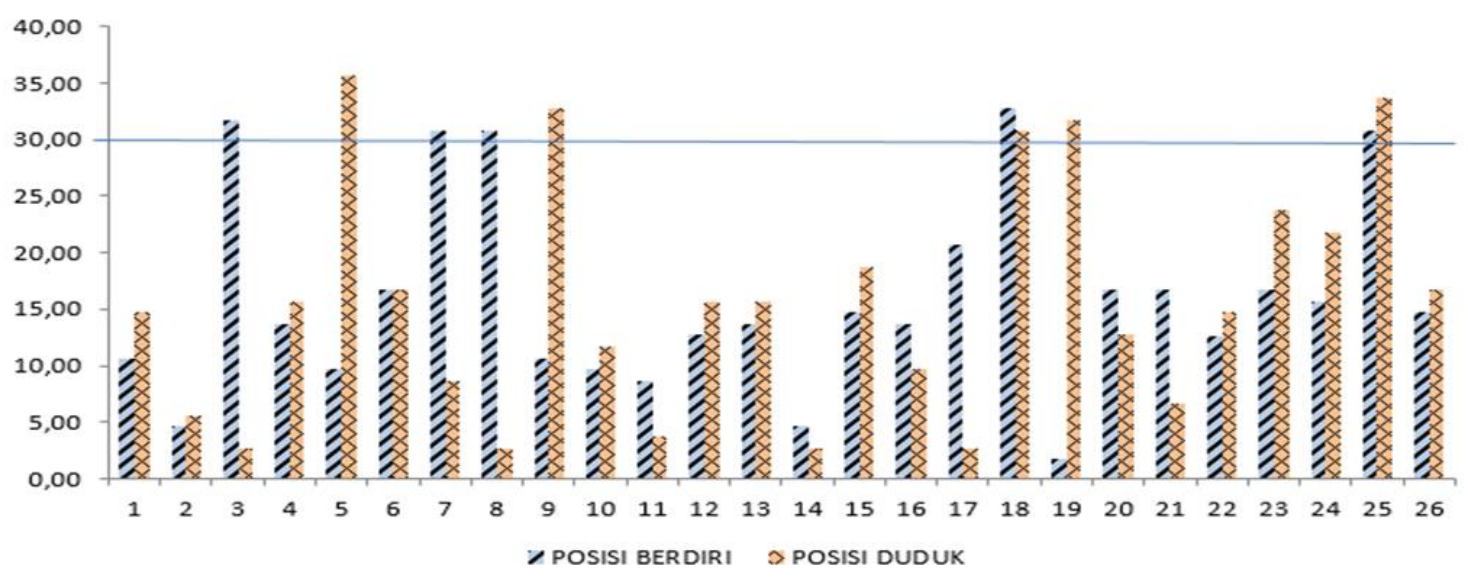

Gambar 3 bBeban kerja fisik usia 20 th -40 th

Gambar 3 menunjukkan bahwa sebanyak 5 pekerja dengan posisi berdiri dan 5 pekerja dengan posisi duduk mengalami beban kerja fisik cukup berat. Beban kerja fisik dengan nilai diantara 30 $\%$ - $60 \%$ menunjukkan beban kerja yang berat, sehingga perlu dilakukan perbaikan; sedangkan nilai < $30 \%$ merupakan indikator beban kerja fisik tidak berat. Pekerja dengan posisi berdiri memerlukan tenaga lebih besar dibanding bekerja dengan posisi duduk karena kaki digunakan sebagai tumpuan tubuh (Kuswana, 2014).

Pekerja sortasi di usia > 40 tahun tersebut hanya melakukan proses sortasi dan terkadang melakukan pemantauan kepada pekerja sortasi yang lain seperti melihat kualitas yang dihasilkan pekerja lain. Perbedaan jenis pekerjaan tersebut dilakukan perusahaan karena menurut perusahaan kesehatan fisik dan tenaga pekerja usia muda lebih kuat daripada pekerja usia lanjut. Suci (2017) menyatakan bahwa kemampuan kerja yang berbeda-beda antara satu karyawan dengan karyawan lainnya dipandang dari 3 aspek yaitu aspek fisik, aspek mental dan aspek penggunaan waktu.

Beban kerja fisik yang timbul akan mengakibatkan gangguan kesehatan jasmani, padahal kesehatan jasmani yang baik sangat dibutuhkan dalam menyelesaikan pekerjaan. Menurut Nala (2003) dalam Sedarmayanti (2011), kesehatan jasmani iomotorik meliputi 10 komponen utama yaitu kekuatan, daya tahan, kecepatan, kelincahan, kelentukan, keseimbangan, kekuatan, koordinasi, ketepatan dan waktu reaksi. Adanya gangguan kesehatan yang dialami pekerja tentunya akan menganggu 10 komponen tersebut dan proses menyelesaikan pekerjaan yang menjadi tanggung jawabnya. Timbulnya ketidaknyamanan dan keluhan kerja tersebut target produk 
yang dihasilkan setiap pekerja tersebut adalah sebanyak $25-28 \mathrm{~kg} / \mathrm{hari}$, hal tersebut jauh dari target produksi perusahaan.

Beban Kerja Psikologis dengan Metode NASA-TLX (National Aeronautics and Space Administration-Task Load Indeks)

Penentuan beban kerja psikologis dengan menggunakan metode NASA-TLX dengan menghitung rata-rata Weighted Workload (WWL) . Nilai WWL didapatkan dengan mengalikan rating dan bobot pada kuesioner NASA - TLX. Berdasarkan kuesinoner NASA-TLX yang telah diisi oleh pekerja sortasi tembakau, didapatkan total rating masing-masing indikator beban kerja psikologis yang berbeda-beda. Hal ini menunjukan bahwa adanya perbedaan beban kerja psikologis yang dialami operator pada masing-masing indikator. Pengukuran beban kerja psikologis pekerja pada bagian sortasi daun tembakau adalah sebagai berikut:

\section{Pekerja usia 20 tahun -40 tahun}

Berdasarkan hasil pengukuran dengan menggunakan kuesioner NASA-TLX dengan perhitungan hasil bobot dan rating (peringkat) kepada responden sehingga adapun hasil presentase dari pengukuran data beban kerja mental pekerja seperti Gambar 4 di bawah ini.

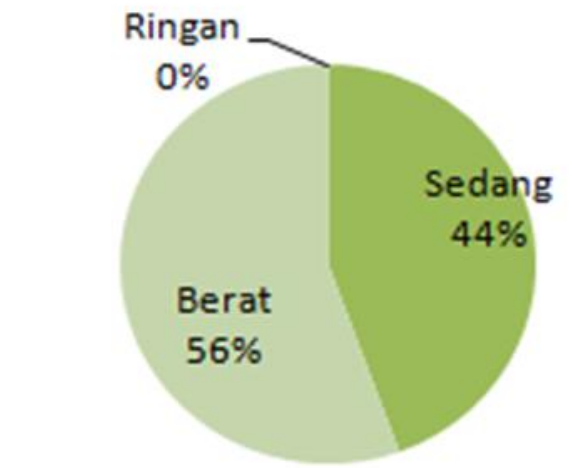

Gambar 4 Persentase beban kerja mental usia 20 tahun - 40 tahun
Berdasarkan Gambar 4 pekerja sortasi usia 20 tahun - 40 memiliki beban kerja mental yang lebih dominan yaitu $56 \%$ atau sebanyak 15 pekerja. Berdasarkan kuesioner NASA-TLX yang terdiri dari enam indikator didapatkan hasil yang paling banyak dirasakan oleh seluruh pekerja sortasi usia 20 tahun - 40 tahun yaitu pada indikator Kebutuhan Fisik (KF), Usaha (U) dan Performansi (P) mencapai nilai mulai dari 70 - 100. Sedangkan untuk indikator Kebutuhan Mental (MD), Kebutuhan Waktu (KW) dan Tingkat Frustasi (TF) tidak terlalu berdampak pada beban kerja pekerja dan dianggap masih rendah yaitu mulai nilai $40-70$.

Berdasarkan nilai yang diberikan oleh masing-masing pekerja indikator Kebutuhan Fisik (KF), Usaha (U) dan Performansi $(\mathrm{P})$ mendapat nilai yang besar dan indikator Kebutuhan Mental (KM) mendapat nilai yang rendah. Hal ini menunjukkan bahwa pada proses sortasi daun tembakau ini hanya sedikit mengalami beban psikologis sehingga pekerja masih merasa aman dan tidak terganggu dengan pekerjaan yang diberikan karena pada pekerjaan ini lebih membutuhkan tenaga atau fisik. Menurut Mutia (2014) berpendapat bahwa Physical Demand (PD) lebih banyak dirasakan dalam menyelesaikan pekerjaannya karena tenaga fisik dan usaha sangat diperlukan.

Menurut Hairy (1989) dan Genaidy (1996) dalam Tarwaka et al (2004), komponen kemampuan kerja fisik dan kesegaran jasmani seseorang ditentukan oleh kekuatan otot, ketahanan otot dan ketahanan kardiovaskuler. Oleh karena itu, lamanya waktu aktivitas dapat bervariasi antara beberapa detik (untuk pekerjaan yang memerlukan kekuatan) sampai beberapa jam (untuk pekerjaan yang memerlukan ketahanan). Hal ini menunjukkan bahwa seberapa besar gabungan usaha mental dan fisik yang dibutuhkan pekerja untuk menyelesaikan 
tanggung jawabnya. Pekerja usia 20 tahun -40 tahun menggunakan aktivitas fisik dan kebutuhan mental sehingga pekerja merasa beban fisik maupun beban mental dapat diseimbangkan.

\section{Pekerja usia $>40$ tahun}

Persentase beban kerja mental pekerja sortasi dengan usia lebih dari 40 tahun disajikan dalam Gambar 5.

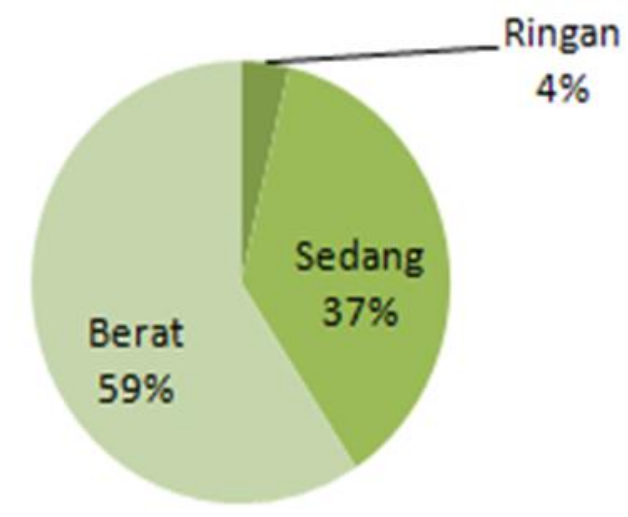

Gambar 5 persentase beban kerja mental $>40$ tahun

Berdasarkan Gambar 5, pekerja sortasi usia > 40 tahun lebih dominan memiliki beban kerja berat dengan nilai rerata $\mathrm{WWL}>80$. Pekerja sortasi usia $>40$ tahun memiliki indikator yang lebih dominan dirasakan yaitu indikator Kebutuhan Fisik (KF), Usaha (U) dan Performansi (P) sama halnya dengan pekerja usia 20 tahun - 40 tahun. Hal ini menunjukkan bahwa pada proses sortasi tembakau pada usia 20 tahun - 40 tahun dan usia > 40 tahun lebih membutuhkan tenaga atau fisik untuk menyelesaikan pekerjaannya. Akan tetapi selain ke 3 indikator tersebut, indikator Tingkat Frustasi pekerja usia > 40 tahun juga berpengaruh karena memiliki nilai rating yang tinggi. Sedangkan untuk indikator lainnya seperti Kebutuhan Mental (KM), dan Kebutuhan Waktu (KW) memiliki nilai rating masih rendah.
Kebutuhan Mental (MD) dan Kebutuhan Waktu (KW) usia > 40 tahun dinilai masih rendah dan tidak begitu berdampak karena rating nilai yang diberikan oleh pekerja yaitu nilai $30-60$. Terdapat beberapa pekerja yang memiliki nilai rating yaitu 100 dan termasuk kategori beban kerja sedang. Hal ini terjadi karena kebutuhan mental tersebut berasal dari diri pekerja (faktor internal) seperti adanya persaingan antar pekerja. Menurut Mutia (2014) mengatakan bahwa Kebutuhan Mental dibutuhkan terutama untuk melakukan proses sortasi karena pekerja harus cermat mengamati dan melakukan sortasi supaya menghasilkan produk yang baik.

Indikator Kebutuhan Fisik (KF), Usaha (U) dan Performansi (P) memiliki nilai rating yang tinggi yaitu antara $70-$ 100. Hal ini menunjukkan bahwa pada proses sortasi tahap 1, tahap 2, dan tahap 3 hanya sedikit mengalami beban psikologis. Pekerja sortasi tahap 1, tahap 2, dan tahap 3 di usia > 40 tahun lebih membutuhkan tenaga dan kemampuan kerja fisik yang tinggi dalam meyelesaikan pekerjaannya.

Tingkat Frustasi (TF) menunjukkan seberapa tingkat putus asa, perasaan tidak aman dan tidak nyaman, terganggu dibandingkan dengan perasaan aman dan nyaman, kepuasan diri dalam melakukan pekerjaannya. Berdasarkan hasil yang didapat, disimpulkan bahwa rata-rata pekerja usia > 40 tahun memiliki ketidaknyaman pada saat bekerja yang berasal dari diri sendiri atau faktor internal seperti kurang puas dalam bekerja dan adanya kondisi tubuh yang menurun karena faktor usia. Menurut Tarwaka et al (2004), faktor internal beban kerja adalah faktor yang berasal dari dalam tubuh itu sendiri sebagai akibat adanya reaksi dari beban kerja eksternal. 


\section{KESIMPULAN}

Berdasarkan hasil pengukuran dengan menggunakan metode \%CVL dan metode NASA-TLX pada beban kerja fisik dan mental yang telah dilakukan di bagian sortasi PTPN X Kebun Kertosari diperoleh kesimpulan bahwa beban kerja fisik lebih dominan dialami oleh pekerja sortasi usia 20 tahun - 40 tahun dengan posisi kerja berdiri sebanyak $37 \%$ dengan jumlah 10 orang dengan persentase \% CVL adalah > $30 \%$. Sedangkan beban kerja mental lebih dominan dirasakan oleh pekerja sortasi usia > 40 tahun, karena masing-masing pekerja memiliki nilai NASA-TLX $>80$.

Timbulnya beban kerja fisik maupun mental tersebut mengakibatkan pekerja lebih sering merasakan ketidaknyamanan bekerja seperti kelelahan dan keluhan di bagian anggota tubuh seperti lutut, leher, punggung. Hal tersebut disebabkan karena faktor usia, banyaknya jenis pekerjaan dan timbul dari faktor internal seperti adanya rasa persaingan bekerja dengan pekerja usia 20 tahun - 40 tahun. Perbaikan yang diperlukan untuk mengurangi beban kerja fisik maupun mental bagi pekerja pada bagian sortasi antara lain dilakukan pembagian tugas kerja, pengurangan pekerja usia lanjut dengan pemberian kompensasi, penambahan jam istirahat dan perbaikan lingkungan kerja.

\section{UCAPAN TERIMAKASIH}

Saya juga ingin mengucapkan terima kasih kepada Fakultas Teknologi Pertanian, Universitas Jember dan PTPN X Kebun Kertosari, Kabupaten Jember yang menyediakan fasilitas untuk penelitian ini. Semoga penelitian ini dapat bermanfaat bagi pembaca.

\section{DAFTAR PUSTAKA}

Hermawan, Bambang., Ansori, M., Hidayat, Rahmat. 2013. Pengukuran dan Analisis Beban Kerja Pegawai Bandara Hang Nadim. Jurnal
Akuntansi, Ekonomi Dan

Manajemen Bisnis: ISSN 23377887. Vol 1(1): 55-67

Kuswana, W. S. 2014. Ergonomi dan K3 (Kesehatan Keselamatan Kerja). Bandung: PT. Remaja Rosdakarya. Cetakan Pertama.

Maharja, R. 2015. Analisis Tingka Kelelahan Kerja Berdasarkan Beban Kerja Fisik Perawat Di Instalasi Rawat Inap RSU Haji Surabaya. Tahune Indonesian Journal of Occupational Safety and Healtahun. PT. Kimia Farma (Persero) Tbk Watudakon, Jombang. Vol 4(1):2 93102

Mutia, M. 2014. Pengukuran Beban Kerja Fisiologis dan Psikologis Pada Operator Pemetikan Teh Di PT Mitra Kerinci. Jurnal Optimasi Sistem Industri: SSN 2088 - 4842. Vol 13(1): 503-517

Sedarmayanti. 2011. Tata Kerja dan Produktivitas Kerja. Penerbit Mandar Maju: Bandung.

Suci R. 2017. Analisis Beban Kerja. Raih Asa Sukses (Penebar Swadaya Grup) : Jakarta.

Tarwaka., Bakri, S. HA., Sudiajeng, Lilik. 2004. Ergonomi untuk Keselamatan Kesehatan Kerja, dan Produktivitas. Surakarta: Universitas Islam. Cetakan Pertama. 